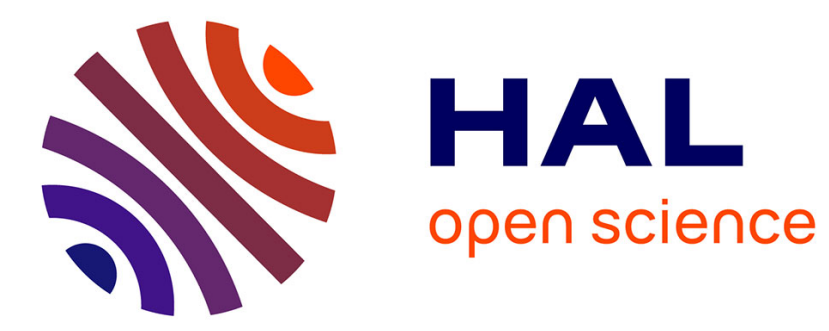

\title{
Structure of proteins unfolded by guanidinium chloride
}

P. Calmettes, Denys Durand, J. Smith, M. Desmadril, P. Minard, R. Douillard

\section{To cite this version:}

P. Calmettes, Denys Durand, J. Smith, M. Desmadril, P. Minard, et al.. Structure of proteins unfolded by guanidinium chloride. Journal de Physique IV Proceedings, 1993, 03 (C8), pp.C8-253-C8-256. 10.1051/jp4:1993849 . jpa-00252280

\section{HAL Id: jpa-00252280 https://hal.science/jpa-00252280}

Submitted on 1 Jan 1993

HAL is a multi-disciplinary open access archive for the deposit and dissemination of scientific research documents, whether they are published or not. The documents may come from teaching and research institutions in France or abroad, or from public or private research centers.
L'archive ouverte pluridisciplinaire HAL, est destinée au dépôt et à la diffusion de documents scientifiques de niveau recherche, publiés ou non, émanant des établissements d'enseignement et de recherche français ou étrangers, des laboratoires publics ou privés. 


\title{
Structure of proteins unfolded by guanidinium chloride
}

\author{
P. CALMETTES, D. DURAND, J.C. SMITH ${ }^{*}$, M. DESMADRIL ${ }^{* *}$, P. MINARD ${ }^{* *}$ and \\ R. DOUILLARD ${ }^{* * *}$
}

Laboratoire Léon Brillouin, CEA-CNRS, CE-Saclay, 91191 Gif-sur-Yvette cedex, France * Département de Biologie Cellulaire et Moléculaire, CE-Saclay, 91191 Gif-sur-Yvette cedex, France

${ }^{* *}$ Laboratoire d'Enzymologie Physico-Chimique et Moléculaire, Groupe de Recherche du CNRS, Université de Paris-Sud, 91405 Orsay, France

${ }^{* * *}$ Laboratoire de Biochimie et Technologie des Protéines, Institut National de la Recherche Agronomique, BP. 527, 44026 Nantes cedex 03, France

\begin{abstract}
Small-angle neutron scattering measurements were performed on two very different proteins unfolded by guanidinium chloride. It is shown that the neutron spectra given by unfolded phosphoglycerate kinase and $\beta$-casein are similar to those of excluded volume homopolymer chains.
\end{abstract}

\section{INTRODUCTION}

A functional native protein generally adopts a specific three-dimensional structure that is determined by its amino-acid sequence. Under certain conditions (temperature, solvent, etc) a protein will denature, changing its structure and loosing activity. The factors influencing the stability of active, folded globular protein conformations are of particular interest to the biophysical community [1]. Also, the pathways by which a protein fold to it native state remain to be determined. Some recent work has resulted in the detection of compact intermediates in the folding pathway.

Whereas crystallography and NMR techniques have allowed the native states of proteins to be well characterized, much less is known about the denatured states. Most available techniques give information on only relatively short length scales. Scattering experiments using neutrons or X-rays can give information on a large proportion of the distances spanned by a denaturated protein. Here we present small-angle scattering data, and their interpretation, on the guanidinium chloride denatured form of two proteins, phosphoglycerate kinase and $\beta$-casein.

\section{MATERIALS AND METHODS}

Two very different proteins were chosen for this study :

i) Yeast phosphoglycerate kinase (PGK), which is globular in its native form and comprises two domains having similar sizes. It contains 415 amino-acids and has a molecular weight of $44525 \mathrm{kDa}$ [2]. Its contour length is about $1430 \AA$ in extended $\beta$-conformation.

ii) Bovine $\beta$-casein, which is partially unfolded in the native state. The $\mathrm{N}$-terminal segment is rich in charged residues whereas the $\mathrm{C}$-terminal one is rather hydrophobic [3]. Generally it forms micellar aggregates. The molecular weight of $\beta$-casein is $23980 \mathrm{kDa}$ and its contour length about $720 \AA$.

No disulfide bond is present in these proteins.

The protein denaturant used was deuteriated guanidinium chloride (Gdn-DCl). In aqueous solution the neutron scattering length density of $\mathrm{Gdn}-\mathrm{DCl}$ is nearly identical to that of heavy water so that small angle-neutron scattering (SANS) mainly arises from the polypeptide and not from the possible solvation shell.

In the samples, protein concentrations were 3 to $5 \mathrm{mg} / \mathrm{ml}$, that is to say about 10 times lower than the one at which they would overlap in the completely unfolded state. The solutions were suitably buffered, the $\mathrm{pD}$ was controlled and kept constant when $\mathrm{Gdn}-\mathrm{DCl}$ was added. Denaturant concentrations were 3.5 to 4.0M, far above the ones required to cause unfolding [4].

SANS experiments were carried out with the PACE and the PAXE spectrometers at the Laboratoire Léon Brillouin. Wavenumber transfers, $\mathrm{q}$, ranged from $0.006 \AA^{-1}$ to $0.7 \AA^{-1}$. The recorded scattering 
spectra were processed as usual [5]. Background incoherent scattering from the unexchanged hydrogen atoms in the proteins was subtracted assuming that coherent scattering vanishes in the range $0.6 \AA^{-1}<\mathrm{q}<0.7 \AA^{-1}$.

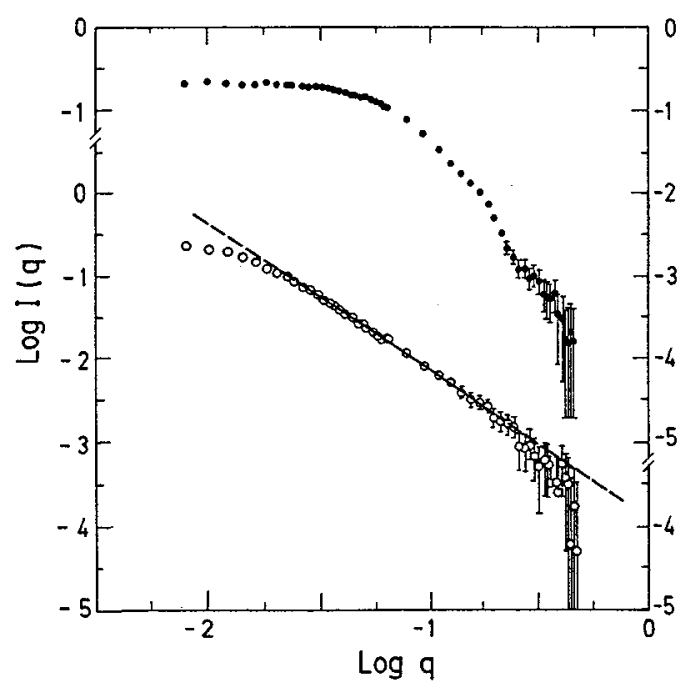

Fig.1 - Log-Log plots of the coherent neutron scattering spectra, $I(q)$, of native $(\bullet)$ and unfolded (o o o) PGK.

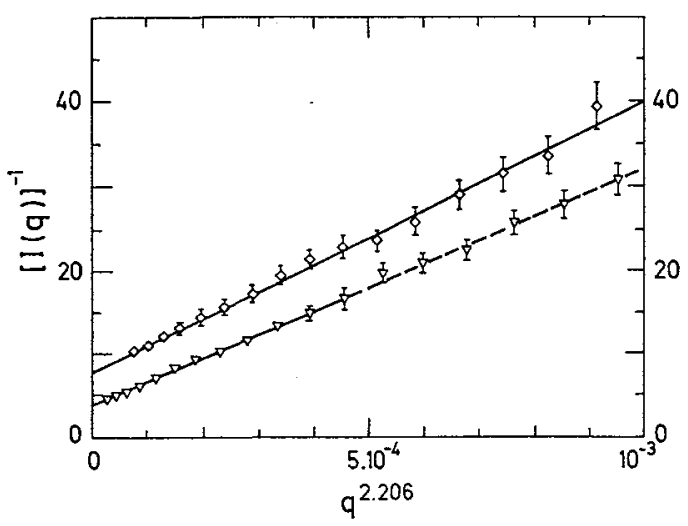

Fig.2 - Plots of $[I(q)]^{-1}$ as a function of $q^{-2.206}$ for unfolded PGK $(\nabla)$ and $\beta$-casein $(\nabla)$. With this approximation to the Debye function the radius of gyration is given by $R_{g}=(a / 0.359 b)^{0.453}$ where a is the slope and $b$ the intercept of the straight line.

\section{RESULTS}

In a previous communication [6] an interpretation of the PGK data was given based on a freelyjointed chain of spheres and molecular mechanics calculations. Here we examine the $q$ dependence of the scattering spectra using some analytical expressions commonly used in polymer theory $[7,8]$.

The coherent scattering spectra, I(q), from native and unfolded PGK are shown in Fig.1. For $q<$ $0.25 \AA^{-1}$, these two spectra are very different and prove that the unfolded protein is much more extended than the native one. Using the Guinier approximation, the gyration radius, $R_{g}$, of the native protein is found to be $(23.0 \pm 0.5) \AA$, in agreement with the value $(23.15 \pm 0.16) \AA$ inferred from $X$-ray small-angle scattering [9]. For unfolded PGK the corresponding value is about $78 \AA$. Considerable uncertainty exists in this figure since the Guinier range is very narrow for a random coil and only few data points were collected in this range. However, for $\mathrm{qR}_{\mathrm{g}} \leq 3$ the scattering spectrum of a random coil can be described by the Debye function [10]

$$
P(x)=I(q) / I(0)=2\left(x^{-2}\right)\left(x-1+e^{-x}\right),
$$

where $\mathrm{x}=\left(\mathrm{qR}_{\mathrm{g}}\right)^{2}$. To within less than $\pm 0.4 \%$ this function can be approximated as $[\mathrm{P}(\mathrm{x})]^{-1}=1+0.359$ $x^{1,103}$ for $x \leq 13$. In this way the radius of gyration of unfolded PGK is found to be $(92 \pm 3) \AA$ as shown in Fig.2.

In the intermediate $q$ range, $0.03 \AA^{-1} \leq \mathrm{q} \leq 0.20 \AA^{-1}$, the scattering spectrum of denatured PGK can be described by

$$
\mathrm{P}(\mathrm{x})=\mathrm{P}_{\infty} \mathrm{x}^{-1 / 2 v},
$$

with $\mathrm{P}_{\infty}=(1.2 \pm 0.2)$ and $v=(0.58 \pm 0.02)$. Such a behavior is typical of an excluded volume chain $[7,8]$. It has already been observed, in particular, for dilute polystyrene solutions in a good solvent [10] for which the value $P_{\infty}=(1.20 \pm 0.17)$ was inferred from the experimental data, assuming that $v=0.588$. Renormalization group values of the universal constants are $v=0.588$ and $P_{\infty}=1.11[8,10]$. 
For large $q$ values, $q \geq 0.20 \AA^{-1}$, the intensity decreases more strongly. In this range, an unfolded protein can be modelled as a wormlike chain with a finite radius of gyration of cross-section [10]. Although inaccurate, the scattering data suggest that the statistical length of the polypeptide chain is not larger than about $10 \AA$.

As shown in Fig.3, similar results were obtained for $\beta$-casein unfolded by Gdn-DCl. Using the previous approximation for the Debye function the radius of gyration is found to be $(69 \pm 2) \AA$. Since the contour length, $L$, of $\beta$-casein is half that of PGK's and since the gyration radius of excluded volume chains scales as $R_{g} \sim L^{2 v}[7,8]$, the experimental values of $R_{g}$ indicate that $\beta$-casein is relatively more swollen than PGK. This suggests that either $\beta$-casein is more rigid than PGK or that repulsive forces between $\beta$-casein residues are stronger than in PGK. This result might be explicable by the fact that $\beta$ casein contains 35 prolyl residues while PGK only have 17 . Prolyl residues are known to rigidify polypeptide chains.

As far as native $\beta$-casein is concerned, Fig.3 shows that aggregates are still present at $4^{\circ} \mathrm{C}$. Thus the present evidence points to the formation of micelles at $4^{\circ} \mathrm{C}$, contrary to what is generally believed $[3,11]$. As shown by the magnitude of $\mathrm{I}(\mathrm{q})$ at small $\mathrm{q}$ values the aggregation number is about 15 at $\mathrm{pD} 7.5$, whereas close to the isoelectric point, at pD5.4 it is about 20 . The scattering spectra look like those of polymer stars but the cross-overs are not located where they would be [12], showing that native $\beta$-casein micelles are not star-shaped [13].

\section{CONCLUSION}

This small-angle neutron scattering study of proteins in denaturating conditions provides a characterization of their unfolded states. Two very different proteins unfolded by guanidinium chloride at molar concentrations were shown to behave as excluded volume polymer chains. This is not expected to significantly change our atomic picture of a configuration of denaturated phosphoglycerate kinase [6]. In addition, the present work provides information about the native

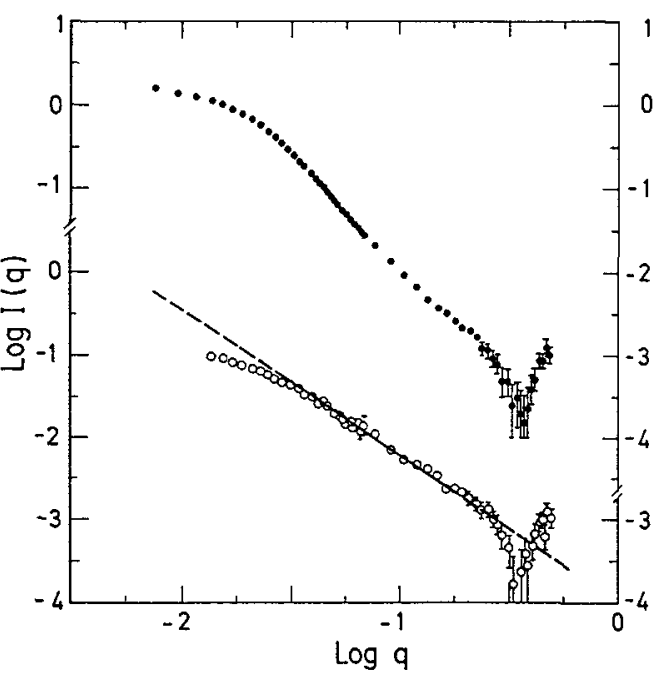

Fig.3 - Log-Log plots of the coherent neutron scattering spectra, I (q), of native (..) and unfolded (o o o) $\beta$-casein. state of $\beta$-casein, which is still a controversial subject.

\section{Acknowledgments}

The technical assistance of J. Coutret is gratefully acknowledged.

\section{REFERENCES}

[1] Creighton, T.E., Curr. Opin. Struct. Biol. (1991) 1, 5.

[2] Watson, H.C., Walker, N.P.C., Shaw, P.J., Bryant, T.N., Wendell, P.L., Fothergill, L.A., Perkins, R.E., Comoy, S.C., Dobson, M.J., Tuite, M.F., Kingsman, A.J. \& Kingsman, S.M., EMBO J. (1982) 1, 1635.

[3] Swaisgood, H.E., Development in Dairy Chemistry, Fox, P.F. Edit., (1982), pp 1-59.

[4] Ballery, N., Minard, P., Desmadril, M., Betton, J.M., Perahia, D., Mouawad, L., Hall, L. \& Yon, J., Protein Engng. (1990) 3, 199.

[5] Cotton, J.-P., Neutron, X-ray and Light Scattering, Lindner,P. \& Zemb, T. Edit., Elsevier Science Publishers B.V., (1991), pp3-18. 
[6] Calmettes, P., Roux, B., Durand, D., Desmadril, M. \& Smith, J.C., J. Mol. Biol. (1993) 231, 840.

[7] de Gennes, P.-G., Scaling Concepts in Polymer Physics, Cornell University, Ithaca, NY, (1979).

[8] des Cloizeaux, J. \& Jannink, G, Polymers in Solution: Their Modelling and Structure, Clarendon Press, Oxford (1990).

[9] Pickover, C.A., Mc Kay, D.B., Engelman, D.M. \& Steitz, T.A., J. Biol. Chem. (1979) 254, 11323.

[10] Rawiso, M., Duplessix, R. \& Picot, C., Macromolecules (1987) 20, 630.

[11] Payens, T.A.J. \& Van Markwijk, B.W., Biochim. Biophys. Acta (1963) 71, 517.

[12] Adam, M. \& Lairez, D., Fractals, 2d issue (1992), (To appear).

[13] Thurn, A., Burchard, W. \& Niki, R., Coll. Polym.Sci. (1987) 265, 653. 